\title{
Atmospheric deposition of inorganic nitrogen in a semi-arid grassland of Inner Mongolia, China
}

\author{
ZHANG Yibo ${ }^{1}$, XU Wen ${ }^{2}$, WEN Zhang ${ }^{1}$, WANG Dandan ${ }^{1}$, HAO Tianxiang ${ }^{1}$, TANG Aohan ${ }^{1}$, \\ LIU Xuejun ${ }^{1 *}$ \\ ${ }^{1}$ College of Resources and Environmental Sciences, China Agricultural University, Beijing 100193, China; \\ ${ }^{2}$ State Key Laboratory of Urban and Regional Ecology, Research Center for Eco-Environmental Sciences, Chinese Academy of \\ Sciences, Beijing 100085, China
}

Abstract: Due to increasing global demand for crop production and energy use, more and more reactive nitrogen $(\mathrm{Nr})$ has been generated and emitted to the environment. As a result, global atmospheric nitrogen $(\mathrm{N})$ deposition has tripled since the industrial revolution and the ecological environment and human health have been harmed. In this study, we measured dry and wet/bulk N deposition from July 2013 to December 2015 in a semi-arid grassland of Duolun County, Inner Mongolia, China. The samples of dry and wet/bulk N deposition were collected monthly with a DELTA (DEnuder for Long Term Atmospheric sampling) system and with Gradko passive samplers and a precipitation gauge. The measured results show that the annual mean concentrations of $\mathrm{NH}_{3}, \mathrm{NO}_{2}, \mathrm{HNO}_{3}$, particulate $\mathrm{NH}_{4}{ }^{+}\left(\mathrm{pNH}_{4}{ }^{+}\right)$and particulate $\mathrm{NO}_{3}{ }^{-}\left(\mathrm{pNO}_{3}{ }^{-}\right)$in atmosphere were $2.33,1.90,0.18,1.42$ and $0.42 \mu \mathrm{g} \mathrm{N} / \mathrm{m}^{3}$, respectively, and that the annual mean volume-weighted concentrations of $\mathrm{NH}_{4}{ }^{+}-\mathrm{N}$ and $\mathrm{NO}_{3}{ }^{-}-\mathrm{N}$ in precipitation were 2.71 and $1.99 \mathrm{mg} \mathrm{N} / \mathrm{L}$, respectively. The concentrations of $\mathrm{Nr}$ components (including $\mathrm{NH}_{3}, \mathrm{NO}_{2}, \mathrm{HNO}_{3}, \mathrm{pNH}_{4}{ }^{+}, \mathrm{pNO}_{3}{ }^{-}, \mathrm{NH}_{4}{ }^{+}-\mathrm{N}$ and $\mathrm{NO}_{3}{ }^{-}-\mathrm{N}$ ) exhibited different seasonal variations. Specifically, $\mathrm{NO}_{2}$ and $\mathrm{HNO}_{3}$ exhibited higher concentrations in autumn than in summer, while the other $\mathrm{Nr}$ components $\left(\mathrm{NH}_{3}, \mathrm{pNH}_{4}{ }^{+}, \mathrm{pNO}_{3}{ }^{-}, \mathrm{NH}_{4}{ }^{+}-\mathrm{N}\right.$ and $\left.\mathrm{NO}_{3}{ }^{-}-\mathrm{N}\right)$ showed the highest values in summer. Based on measured concentrations of $\mathrm{Nr}$ components and their deposition velocities estimated using the GEOS-Chem global atmospheric chemical transport model, the calculated annual mean dry deposition fluxes were 3.17, 1.13, $0.63,0.91$ and $0.36 \mathrm{~kg} \mathrm{~N} /\left(\mathrm{hm}^{2} \bullet\right.$ a) for $\mathrm{NH}_{3}, \mathrm{NO}_{2}, \mathrm{HNO}_{3}, \mathrm{pNH}_{4}{ }^{+}$and $\mathrm{pNO}_{3}^{-}$, respectively, and the calculated annual mean wet/bulk deposition fluxes were 5.37 and $3.15 \mathrm{~kg} \mathrm{~N} /\left(\mathrm{hm}^{2} \cdot \mathrm{a}\right)$ for $\mathrm{NH}_{4}{ }^{+}-\mathrm{N}$ and $\mathrm{NO}_{3}{ }^{-}-\mathrm{N}$, respectively. The estimated annual $\mathrm{N}$ deposition (including dry $\mathrm{N}$ deposition and wet/bulk N deposition) reached $14.7 \mathrm{~kg} \mathrm{~N} /\left(\mathrm{hm}^{2} \cdot \mathrm{a}\right)$ in grassland of Duolun County, approaching to the upper limit of the $\mathrm{N}$ critical load (10-15 $\mathrm{kg} \mathrm{N} /\left(\mathrm{hm}^{2} \cdot a\right)$ ). Dry and wet/bulk deposition fluxes of all $\mathrm{Nr}$ components (with an exception of $\mathrm{HNO}_{3}$ ) showed similar seasonal variations with the maximum deposition flux in summer and the minimum in winter. Reduced $\mathrm{Nr}$ components (e.g., gaseous $\mathrm{NH}_{3}$ and $\mathrm{pNH}_{4}{ }^{+}$in atmosphere and $\mathrm{NH}_{4}{ }^{+}-\mathrm{N}$ in precipitation) dominated the total $\mathrm{N}$ deposition at the sampling site (accounted for $64 \%$ of the total $\mathrm{N}$ deposition), suggesting that the deposited atmospheric $\mathrm{Nr}$ mainly originated from agricultural activities. Considering the projected future increases in crop and livestock production in Inner Mongolia, the ecological and human risks to the negative effects of increased $\mathrm{N}$ deposition could be increased if no mitigation measures are taken.

Keywords: atmospheric reactive nitrogen; dry deposition; wet/bulk deposition; reduced nitrogen; grassland ecosystem; Inner Mongolia

Citation: ZHANG Yibo, XU Wen, WEN Zhang, WANG Dandan, HAO Tianxiang, TANG Aohan, LIU Xuejun. 2017. Atmospheric deposition of inorganic nitrogen in a semi-arid grassland of Inner Mongolia, China. Journal of Arid Land, 9(6): 810-822. https://doi.org/10.1007/s40333-017-0071-x

*Corresponding author: LIU Xuejun (E-mail: liu310@cau.edu.cn)

The first and second authors contributed equally to this work.

Received 2017-04-20; revised 2017-08-31; accepted 2017-09-19

CC Xinjiang Institute of Ecology and Geography, Chinese Academy of Sciences, Science Press and Springer-Verlag GmbH Germany 2017 


\section{Introduction}

Nitrogen $(\mathrm{N})$ is a primary controlling factor for the net primary productivity of many ecological ecosystems, especially in regions with low levels of N supplies (Wedin and Tilman, 1996; Liu et al., 2011). It plays a significant role in increasing food production and stimulating plant growth (Gruber and Galloway, 2008; He et al., 2016). With increasing human activity, a large amount of reactive nitrogen $(\mathrm{Nr})$ was generated and emitted to the environment, thus influencing the $\mathrm{N}$ balance in ecosystems. Specifically, large consumption of fossil fuels, heavy application of chemical $\mathrm{N}$ fertilizers, excessive population growth, and intensive livestock production all resulted in a dramatic increase in $\mathrm{Nr}$ emissions in recent decades (Galloway et al., 2004; Fowler et al., 2013). As a result, atmospheric $\mathrm{N}$ emission increased from $34 \mathrm{Tg} \mathrm{N}$ in 1860 to $109 \mathrm{Tg} \mathrm{N}$ in 2010, and the value is projected to reach $270 \mathrm{Tg} \mathrm{N}$ in 2050 (Galloway et al., 2004; Fowler et al., 2013). After the release of $\mathrm{Nr}$ compounds into the atmosphere, they normally experience a variety of physical and chemical transformation processes before undergoing wet or dry depositions, leading to adverse impacts on the ecological environment and human health.

In China, rapid economic development including agricultural and industrial expansions has resulted in a sharp increase in the $\mathrm{N}$ deposition (Duan et al., 2016). Based on an integrated analysis of historical data and the monitoring data, Liu et al. (2013) showed that annual bulk $\mathrm{N}$ deposition had increased by approximately $8 \mathrm{~kg} \mathrm{~N} / \mathrm{hm}^{2}$ in the $2000 \mathrm{~s}$ compared with that in the 1980 s and that this growth trend will persist in the future. Jia et al. (2016) evaluated the present dry $\mathrm{N}$ deposition rate in China using the results from satellite observations and found that the present dry $\mathrm{N}$ deposition rate had reached up to $7.5 \mathrm{Tg} \mathrm{N} / \mathrm{a}$. This estimation was more or less consistent with the recent model findings of Zhao et al. (2017), who reported that the dry deposition rate was $6.4 \mathrm{Tg} \mathrm{N} / \mathrm{a}$. Generally speaking, excessive $\mathrm{N}$ deposition can negatively cause a wide range of environmental issues, such as soil acidification, lake eutrophication, biodiversity loss, and $\mathrm{N}_{2} \mathrm{O}$ emission increases (Bobbink et al., 2010; Duprè et al., 2010; Song et al., 2012). Furthermore, $\mathrm{NH}_{3}$ and $\mathrm{NO}_{\mathrm{x}}$ are important precursors for the secondary inorganic aerosol formation and can thus promote the formation of haze (Pan et al., 2016a, b).

Grassland in China is the most vastly-distributed vegetation type, covering nearly $40 \%$ of the surface area (Ni, 2004). Inner Mongolia grassland, an important part of China's grassland, makes a great contribution to the global carbon cycle. As an important component of green ecological barrier in North China, the Inner Mongolia grassland is of vital significance for the maintenance and conservation of biodiversity. However, in recent years, due to influences of over-fertilization, unreasonable utilization of land resources, the grassland continues to suffer from land degradation and desertification (Wang et al., 2017). Negative impacts of $\mathrm{N}$ deposition on grassland biodiversity have been observed by numerous field experiments in China (Bai et al., 2010; Duprè et al., 2010) and abroad (e.g., Bobbink et al., 2010). The negative impacts include ultimate alteration of the community structure and ultimate reduction of the primary net productivity in grassland ecosystems (Ceulemans et al., 2017; Tang et al., 2017).

However, opposing voices questioned the aforementioned negative impacts of $\mathrm{N}$ deposition and speculated that the negative impacts may be artifacts of simulation manipulations (Ochoa-Hueso et al., 2011; Nogueira et al., 2017). In recent years, Chinese scientists have also conducted a series of studies to quantify the impacts of N deposition on grasslands (Liu et al., 2011; Song et al., 2012; Li et al., 2015). However, observations, especially long-term continuous observations, of the wet/bulk and dry depositions in the grassland ecosystems of Inner Mongolia are still scarce and most of the existing observations are from the North China Plain (Shen et al., 2009; Pan et al., 2012; Luo et al., 2013; Xu et al., 2016), the Yangtze River Delta (Yang et al., 2010), and the Pearl River Delta (Wang et al., 2013).

In order to fill the research geographic gaps of $\mathrm{N}$ deposition in grassland ecosystems and to provide data for national evaluation of $\mathrm{N}$ deposition, we conducted a 3-year study in grassland of Duolun County in the southeastern part of the Inner Mongolia grassland. The purposes of this work were: (1) to estimate the concentrations of $\mathrm{Nr}$ components and the deposition fluxes, and (2) to characterize the seasonal variations of dry and wet/bulk $\mathrm{N}$ deposition. 


\section{Materials and methods}

\subsection{Study site}

The study was conducted in a semi-arid grassland in Duolun County, Inner Mongolia Autonomous Region, China. The sampling site is situated in a meteorological observation station of the Chinese Academy of Sciences $\left(42^{\circ} 22^{\prime} \mathrm{N}, 116^{\circ} 49^{\prime} \mathrm{E} ; 1324 \mathrm{~m}\right.$ a.s.l.). This site features a typical semi-arid continental monsoon climate. The average annual precipitation is $380 \mathrm{~mm}$ and the maximum precipitation occurs in July. The growing season generally starts in May and continues until the end of September, with a length of about 150 days. Precipitation amount in the growing season accounts for $88 \%$ of the total annual precipitation. The annual average temperature is $2.2^{\circ} \mathrm{C}$ and the monthly average temperature ranges from $-16.9^{\circ} \mathrm{C}$ in January to $19.4^{\circ} \mathrm{C}$ in July. The dominant soil type is chestnut soil. Livestock grazing and crop cultivation are the two major land-use practices in this area.

\subsection{Sampling and $\mathrm{N}$ deposition analysis}

\subsubsection{Dry $\mathrm{N}$ deposition}

Reactive nitrogen $(\mathrm{Nr})$ components, including $\mathrm{NH}_{3}, \mathrm{NO}_{2}, \mathrm{HNO}_{3}$, particulate $\mathrm{NH}_{4}^{+}\left(\mathrm{pNH}_{4}{ }^{+}\right)$and particulate $\mathrm{NO}_{3}{ }^{-}\left(\mathrm{pNO}_{3}{ }^{-}\right)$, were sampled monthly from July 2013 to December 2015. $\mathrm{NH}_{3}, \mathrm{HNO}_{3}$, $\mathrm{pNH}_{4}{ }^{+}$and $\mathrm{pNO}_{3}{ }^{-}$were measured with a DELTA (DEnuder for Long Term Atmospheric sampling) system. The DELTA system consisted of three parts: a circular sampling chain with diffusers and a particle collection device, a small low-volume pump $(0.2-0.4 \mathrm{~L} / \mathrm{min})$ and a high-precision gas flow meter. Details about the DELTA system have described in detail previously (Flechard et al., 2011; Xu et al., 2015). Briefly, when ambient air passes through the DELTA system, $\mathrm{HNO}_{3}$ and other acidic gases are captured by two long diffusion tubes coated on the inner wall with a mixed solution of $10 \mathrm{~g} / \mathrm{L} \mathrm{K}{ }_{2} \mathrm{CO}_{3}$ and $10 \mathrm{~g} / \mathrm{L}$ glycerol in methanol; and $\mathrm{NH}_{3}$ is captured by another two short diffusion tubes coated with citric acid $(5 \%(\mathrm{~m} / \mathrm{v})$ in methanol). Subsequently, the acidic particulate aerosols are collected by a filter membrane with basic adsorbent in the DELTA train membrane system, and the alkaline particulate aerosols are collected by a membrane with acidic adsorbent.

$\mathrm{NO}_{2}$ was monitored with Gradko passive tubes (Gradko International Limited, Winchester, UK), which are composed of an acrylic acid tube $(71.0 \mathrm{~mm}$ in length and $11.0 \mathrm{~mm}$ in internal diameter), two polyethylene caps (gray and white, located at both ends of the diffuser) and two layers of stainless steel wire. The $\mathrm{NO}_{2}$ was absorbed into $20 \%$ triethanolamine solution coated onto two stainless steel wire meshes in the gray cap. The sampling heights of the DELTA system and $\mathrm{NO}_{2}$ diffusion tubes were kept at $2 \mathrm{~m}$ above ground. Three $\mathrm{NO}_{2}$ sampler replicates were deployed for monthly sampling. Exposed DELTA sample trains and $\mathrm{NO}_{2}$ diffusion tubes were replaced with new ones at the end of a month and were preserved in a refrigerator at $4{ }^{\circ} \mathrm{C}$, and then analyzed immediately after collection. The gaseous $\mathrm{HNO}_{3}$ collected in glass denuders of the DELTA sampling train system and the $\mathrm{pNO}_{3}{ }^{-}$on the filter membrane were extracted using $10 \mathrm{~mL} 0.05 \%$ $\mathrm{H}_{2} \mathrm{O}_{2}$ solution, and the $\mathrm{NH}_{3}$ and $\mathrm{pNH}_{4}{ }^{+}$denuders and membranes were extracted using 6 and 10 $\mathrm{mL}$ high purity water, respectively. An AA3 continuous flow analyzer (Bran+Luebbe $\mathrm{GmbH}$, Norderstedt, Germany) was utilized to measure $\mathrm{NH}_{4}{ }^{+}$and $\mathrm{NO}_{3}{ }^{-}$concentrations in the extracted solutions. $\mathrm{NO}_{2}$ in the Gradko passive sampler was extracted with a mixed solution of sulfonamide, $\mathrm{H}_{3} \mathrm{PO}_{4}$, and N-1-naphthylethylene-diamine, and $\mathrm{NO}_{2}$ concentration was determined by absorbance at a wavelength of $542 \mathrm{~nm}$. For quality assurance purposes, we set up monthly blank samples both in the laboratory and in the field and analyzed them using the same procedures outlined above.

\subsubsection{Wet/bulk N deposition}

Wet/bulk N deposition was collected by a precipitation gauge (SDM6, Tianjin Weather Equipment Inc., China) at the sampling site from May 2013 to November 2015. The precipitation gauge was a passive sampler without power input, consisting mainly of a stainless steel funnel and a glass container. Precipitation was automatically collected by the precipitation gauge and the amount was measured with a graduated cylinder of the gauge. Before being taken to the laboratory of 
China Agricultural University for chemical analysis, the collected precipitation was recorded, mixed, and put into a clean polyethylene bottle $(50 \mathrm{~mL})$ inside a refrigerator $\left(-18^{\circ} \mathrm{C}\right)$. It should be noted that we rinsed the precipitation gauge with high purity water after each collection to avoid sample contamination. The precipitation samples were filtered by $0.45 \mu \mathrm{m}$ filter membranes, then $15 \mathrm{~mL}$ filtered fluid was taken out, frozen and kept in a polyethylene bottle. $\mathrm{NH}_{4}{ }^{+}-\mathrm{N}$ and $\mathrm{NO}_{3}{ }^{-} \mathrm{N}$ were determined by a continuous flow analyzer (Bran+Luebbe GmbH, Norderstedt, Germany), as mentioned above, within a month.

\subsection{Calculations of $\mathbf{N}$ deposition flux}

We calculated the wet/bulk $\mathrm{N}$ deposition flux based on $\mathrm{NH}_{4}{ }^{+}-\mathrm{N}$ and $\mathrm{NO}_{3}{ }^{-}-\mathrm{N}$ concentrations and precipitation amount in each precipitation event. The volume-weighted mean concentration of $\mathrm{Nr}$ components $\left(C_{w} ; \mathrm{mg} \mathrm{N} / \mathrm{L}\right)$ was obtained with Equation 1:

$$
C_{w}=\frac{\sum_{i=1}^{n}\left(C_{i} \times P_{i}\right)}{\sum_{i=1}^{n} P_{i}},
$$

where $C_{i}$ is the inorganic $\mathrm{Nr}$ concentration in the $i^{\text {th }}$ precipitation event $(\mathrm{mg} \mathrm{N} / \mathrm{L}) ; P_{i}$ is the precipitation amount in the $i^{\text {th }}$ precipitation event $(\mathrm{mm}) ; n$ is the number of precipitation events. The wet/bulk deposition flux of $\mathrm{Nr}$ components $\left(D_{w} ; \mathrm{kg} \mathrm{N} / \mathrm{hm}^{2}\right)$ was calculated using Equation 2:

$$
D_{w}=0.01 \times C_{w} \times \sum_{i=1}^{n} P_{i} .
$$

Dry $\mathrm{N}$ deposition is affected by various chemical and environmental factors like meteorological conditions, physicochemical properties of $\mathrm{Nr}$ components, roughness of underlying surface, and the ability of the underlying surface to capture and absorb $\mathrm{Nr}$ components (Flechard et al., 2011). Extra issues arise concerning characteristics of the bidirectional flow of $\mathrm{N}$, making the quantification of dry deposition a challenge. $\mathrm{Nr}$ emission is the predominant process when the concentration in the surface is higher than that in the atmosphere, while deposition is expected when the gradient reverses. Inferential models have previously been extensively used as operational tools to determine dry $\mathrm{N}$ deposition in many monitoring networks all over the world, such as NADP (National Atmospheric Deposition Program) and EMEP (European Monitoring and Evaluation Program). Using the inferential method, we obtained the monthly dry deposition flux of $\mathrm{Nr}$ components by multiplying the concentrations of $\mathrm{Nr}$ components measured in our field samples with deposition velocities obtained from simulation results of a global atmospheric chemical transport model. The dry deposition flux of $\mathrm{Nr}$ components was expressed by Equation 3:

$$
F_{d}=C_{z} \times V_{d},
$$

where $F_{d}$ is the dry deposition flux of an $\mathrm{Nr}$ component $\left(\mathrm{kg} \mathrm{N} / \mathrm{hm}^{2}\right) ; C_{z}$ is the measured atmospheric concentration of the $\mathrm{Nr}$ component $\left(\mu \mathrm{g} \mathrm{N} / \mathrm{m}^{3}\right)$; and $V_{d}$ is the dry deposition velocity $(\mathrm{cm} / \mathrm{s})$. It should be noted that $V_{d}$ was obtained from a nested-grid version of the Goddard Earth Observing System (GEOS)-Chem chemical transport model (Chem CTM) for Asia. The model has a spatial horizontal resolution of $0.50^{\circ}$ latitude $\times 0.67^{\circ}$ longitude and a temporal resolution of 6 h. The $V_{d}$ estimation of dry $\mathrm{N}$ deposition follows a standard big-leaf resistance-in-series model, which is determined by meteorological conditions and land-use types (grassland in the present study). We averaged the hourly $V_{d}$ data to obtain monthly values of dry deposition velocities of all $\mathrm{Nr}$ components. Details about the model description and the simulation of dry $\mathrm{N}$ deposition fluxes can be found in Zhang et al. (2012). It should be mentioned that a part of the wet/bulk and dry N deposition results (e.g., data from July 2013 to September 2014) in present work was published previously by $\mathrm{Xu}$ et al. (2015).

\section{Results}

\subsection{Concentrations of $\mathrm{Nr}$ components in atmosphere}

Monthly concentrations of $\mathrm{NH}_{3}, \mathrm{NO}_{2}, \mathrm{HNO}_{3}, \mathrm{pNH}_{4}{ }^{+}$and $\mathrm{pNO}_{3}{ }^{-}$in atmosphere were in the ranges 
of $0.34-6.79,0.24-6.92,0.01-0.53,0.84-5.63$ and $0.33-1.48 \mu \mathrm{g} \mathrm{N} / \mathrm{m}^{3}$, respectively, from July 2013 to December 2015 (Fig. 1). The seasonal variation of $\mathrm{NH}_{3}$ was remarkable with an annual mean concentration of $2.33 \mu \mathrm{g} \mathrm{N} / \mathrm{m}^{3}$. The highest concentration of $\mathrm{NH}_{3}$ occurred in summer (June-August) while the lowest in winter (December-February). The annual mean concentration of $\mathrm{NO}_{2}$ was $1.90 \mu \mathrm{g} \mathrm{N} / \mathrm{m}^{3}$ with the highest concentration in April and the lowest in January. The annual mean concentration of $\mathrm{HNO}_{3}$ was $0.18 \mu \mathrm{g} \mathrm{N} / \mathrm{m}^{3}$. Compared with $\mathrm{NH}_{3}$ and $\mathrm{NO}_{2}$, the monthly concentrations of $\mathrm{HNO}_{3}$ were lower and also less variable, except that the concentration in September was notably higher than those in other months. The lowest concentration of $\mathrm{HNO}_{3}$ occurred in May. The annual mean concentration of $\mathrm{pNH}_{4}{ }^{+}$was $1.42 \mu \mathrm{g} \mathrm{N} / \mathrm{m}^{3}$ with the maximum monthly concentration in July and the minimum in January. Similar to $\mathrm{pNH}_{4}{ }^{+}$, the monthly concentrations of $\mathrm{pNO}_{3}{ }^{-}$also showed the highest value in July. The annual mean concentration of $\mathrm{pNH}_{4}{ }^{+}$was $0.62 \mu \mathrm{g} \mathrm{N} / \mathrm{m}^{3}$.

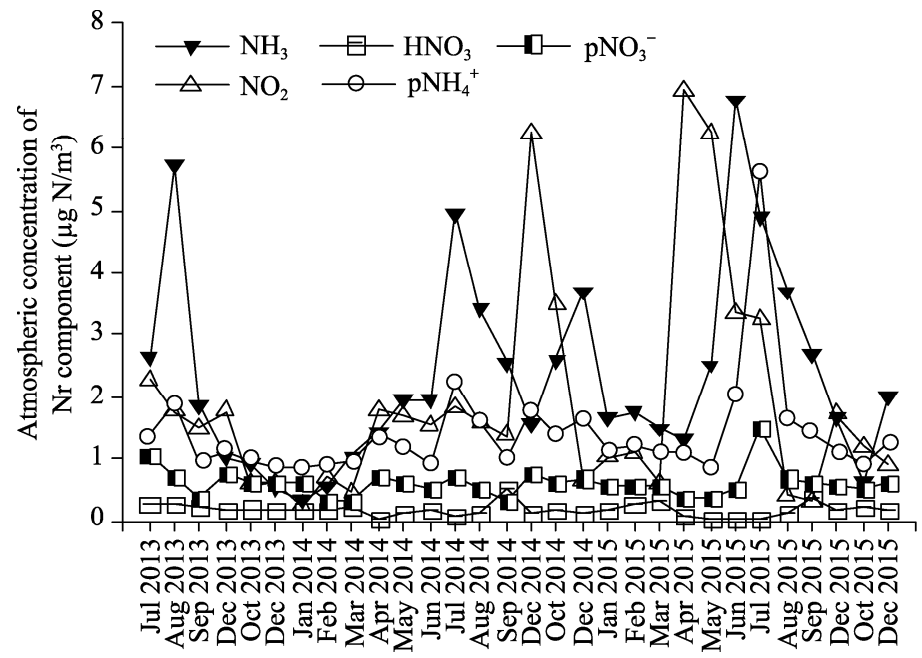

Fig. 1 Monthly concentrations of $\mathrm{Nr}$ (reactive nitrogen) components (including $\mathrm{NH}_{3}, \mathrm{NO}_{2}, \mathrm{HNO}_{3}, \mathrm{pNH}_{4}{ }^{+}$and $\mathrm{pNO}_{3}{ }^{-}$) in the atmosphere from July 2013 to December 2015

\subsection{Concentrations of $\mathrm{Nr}$ components in precipitation}

During the monitoring period (i.e., from May 2013 to December 2015), the monthly volume-weighted concentrations of $\mathrm{NH}_{4}{ }^{+}$and $\mathrm{NO}_{3}{ }^{-}$in precipitation varied from 0.27 to 12.19 and 0.10 to $11.68 \mathrm{mg} \mathrm{N} / \mathrm{L}$, respectively (Fig. 2). The average annual concentrations of $\mathrm{NH}_{4}^{+}-\mathrm{N}$ and $\mathrm{NO}_{3}{ }^{-} \mathrm{N}$ in precipitation were 2.71 and $1.99 \mathrm{mg} \mathrm{N} / \mathrm{L}$, respectively. Compared with $\mathrm{NO}_{3}{ }^{-} \mathrm{-}$, the $\mathrm{NH}_{4}{ }^{+} \mathrm{N}$ concentration in precipitation was generally higher except for values in September and October, 2013. Higher concentrations of $\mathrm{NO}_{3}{ }^{-} \mathrm{N}$ and $\mathrm{NH}_{4}{ }^{+}-\mathrm{N}$ were observed in the months (February-May) when the precipitation was lower, while lower concentrations were always accompanied by higher monthly precipitation (June-September). The precipitation amount, to a large extent, affected the concentrations of $\mathrm{NO}_{3}{ }^{-}-\mathrm{N}$ and $\mathrm{NH}_{4}{ }^{+}-\mathrm{N}$.

\subsection{N deposition flux}

Monthly dry deposition velocities of each $\mathrm{Nr}$ component are listed in Table 1. Based on these values, we calculated the annual dry deposition fluxes of $\mathrm{NH}_{3}, \mathrm{NO}_{2}, \mathrm{HNO}_{3}, \mathrm{pNH}_{4}{ }^{+}$and $\mathrm{pNO}_{3}{ }^{-}$ (Fig. 3). Specifically, annual dry deposition fluxes were $3.17,1.13,0.63,0.91$ and $0.36 \mathrm{~kg}$ $\mathrm{N} /\left(\mathrm{hm}^{2} \cdot \mathrm{a}\right)$ for $\mathrm{NH}_{3}, \mathrm{NO}_{2}, \mathrm{HNO}_{3}, \mathrm{pNH}_{4}{ }^{+}$and $\mathrm{pNO}_{3}{ }^{-}$, respectively, during the monitoring period. It should be noted that the monitoring data in 2013 were not included in the calculation of annual dry deposition flux since the data were not complete for 2013. During the monitoring period (excluding the data of 2013), the summed annual dry deposition flux of the five atmospheric $\mathrm{Nr}$ components (i.e., $\mathrm{NH}_{3}, \mathrm{NO}_{2}, \mathrm{HNO}_{3}, \mathrm{pNH}_{4}{ }^{+}$and $\mathrm{pNO}_{3}{ }^{-}$) averaged $6.21 \mathrm{~kg} \mathrm{~N} /\left(\mathrm{hm}^{2} \cdot \mathrm{a}\right)$. Due to the high concentration of $\mathrm{NH}_{3}$, the dry deposition flux of $\mathrm{NH}_{3}$ was also the largest one among the five 


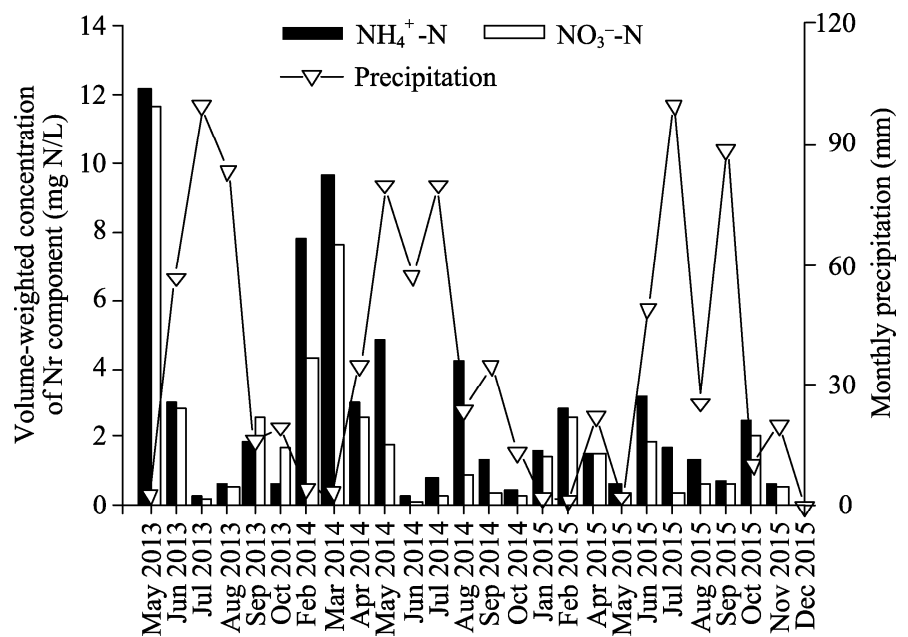

Fig. 2 Monthly volume-weighted concentrations of $\mathrm{Nr}$ components (including $\mathrm{NO}_{3}{ }^{-}-\mathrm{N}$ and $\mathrm{NH}_{4}{ }^{+}-\mathrm{N}$ ) in precipitation from May 2013 to December 2015

atmospheric $\mathrm{Nr}$ components, followed by $\mathrm{NO}_{2}, \mathrm{HNO}_{3}, \mathrm{pNH}_{4}^{+}$and $\mathrm{pNO}_{3}{ }^{-}$. Generally, $\mathrm{NH}_{3}$ contributed $51 \%$ to the total dry $\mathrm{N}$ deposition, being higher than the combined contribution of the other four $\mathrm{Nr}$ components (49\%).

From 2013 to 2015, the annual wet/bulk deposition fluxes fluctuated in the ranges of 3.22-7.90 $\mathrm{kg} \mathrm{N} /\left(\mathrm{hm}^{2} \cdot \mathrm{a}\right)$ for $\mathrm{NH}_{4}{ }^{+}-\mathrm{N}$ and $2.72-3.38 \mathrm{~kg} \mathrm{~N} /\left(\mathrm{hm}^{2} \cdot \mathrm{a}\right)$ for $\mathrm{NO}_{3}{ }^{-}-\mathrm{N}$. The average annual wet/bulk deposition flux of $\mathrm{NH}_{4}{ }^{+}-\mathrm{N}\left(5.37 \mathrm{~kg} \mathrm{~N} /\left(\mathrm{hm}^{2} \cdot \mathrm{a}\right)\right)$ was 1.7 times that of $\mathrm{NO}_{3}{ }^{-}-\mathrm{N}\left(3.16 \mathrm{~kg} \mathrm{~N} /\left(\mathrm{hm}^{2} \cdot \mathrm{a}\right)\right)$. The annual wet/bulk deposition flux was averagely $8.53 \mathrm{~kg} \mathrm{~N} /\left(\mathrm{hm}^{2} \cdot \mathrm{a}\right)$ and the annual N deposition (dry deposition plus wet/bulk deposition) flux was averagely $14.73 \mathrm{~kg} \mathrm{~N} /\left(\mathrm{hm}^{2} \cdot \mathrm{a}\right)$.

Table 1 Monthly dry deposition velocities of different atmospheric $\mathrm{Nr}$ components

\begin{tabular}{cccccc}
\hline \multirow{2}{*}{ Month } & $\mathrm{NH}_{3}$ & $\mathrm{NO}_{2}$ & $\mathrm{HNO}_{3}$ & $\mathrm{pNH}_{4}{ }^{+}$ & $\mathrm{pNO}_{3}{ }^{-}$ \\
\cline { 2 - 6 } & & & $(\mathrm{cm} / \mathrm{s})$ & \\
\hline January & 0.26 & 0.01 & 0.15 & 0.13 & 0.13 \\
February & 0.30 & 0.01 & 0.17 & 0.15 & 0.15 \\
March & 0.30 & 0.03 & 0.37 & 0.18 & 0.18 \\
April & 0.30 & 0.07 & 0.87 & 0.22 & 0.22 \\
May & 0.40 & 0.24 & 2.06 & 0.26 & 0.26 \\
June & 0.55 & 0.38 & 2.44 & 0.27 & 0.27 \\
July & 0.55 & 0.38 & 2.36 & 0.23 & 0.23 \\
August & 0.53 & 0.34 & 2.26 & 0.24 & 0.24 \\
September & 0.46 & 0.26 & 2.19 & 0.22 & 0.22 \\
October & 0.34 & 0.13 & 1.59 & 0.16 & 0.16 \\
November & 0.27 & 0.03 & 0.67 & 0.13 & 0.13 \\
December & 0.27 & 0.01 & 0.14 & 0.13 & 0.13 \\
\hline
\end{tabular}

\section{Discussion}

\subsection{Concentrations of $\mathrm{Nr}$ components in atmosphere and precipitation}

In China, fossil fuel is intensively consumed to support the growth of population and economy, leading to large amounts of $\mathrm{Nr}$ emissions to the atmosphere and subsequent $\mathrm{N}$ deposition to the ecological ecosystems. At the same time, lack of effective measures to control atmospheric $\mathrm{Nr}$ emissions aggravates the increasing trend of $\mathrm{N}$ deposition to the ecological ecosystems (Liu et al., 


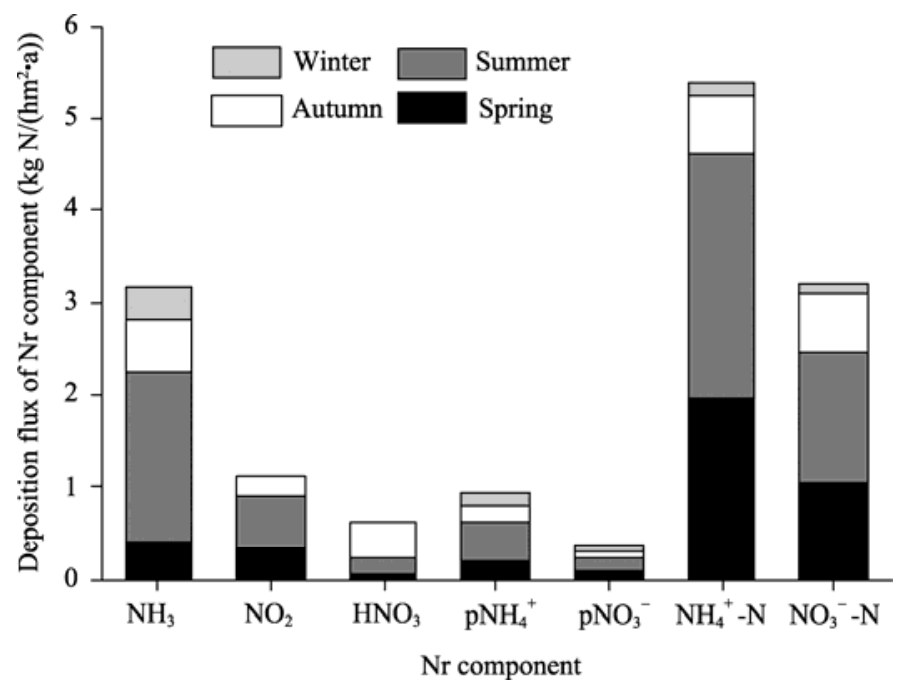

Fig. 3 Seasonal variations of dry and wet/bulk deposition fluxes of $\mathrm{Nr}$ components $\left(\mathrm{NH}_{3}, \mathrm{NO}_{2}, \mathrm{HNO}_{3}, \mathrm{pNH}_{4}{ }^{+}\right.$, $\mathrm{pNO}_{3}{ }^{-}, \mathrm{NH}_{4}{ }^{+}-\mathrm{N}$ and $\mathrm{NO}_{3}{ }^{-}-\mathrm{N}$ )

2013). Consequently, China has become one of the world's hotspots in N deposition (Vet et al., 2014) and suffered from the threat of continued and serious $\mathrm{Nr}$ pollution.

The current study found that monthly average concentrations of $\mathrm{Nr}$ components in atmosphere and in precipitation in grassland of Inner Mongolia were considerably lower than those measured in two well-developed regions: North China Plain (Luo et al., 2013; Xu et al., 2016) and Southwest China (Kuang et al., 2016). Due to the burning of fossil fuels and the intensified agricultural activities and livestock production, the North China Plain has been a hotspot of $\mathrm{NH}_{3}$ in China (Liu et al., 2016; Pan et al., 2016a) with the largest annual mean $\mathrm{NH}_{3}$ concentration of $16.9 \pm 5.9 \mu \mathrm{g} \mathrm{N} / \mathrm{m}^{3}$ in Quzhou (Xu et al., 2016). This value is far higher than the annual mean $\mathrm{NH}_{3}$ concentration observed from this study $\left(2.33 \mu \mathrm{g} \mathrm{N} / \mathrm{m}^{3}\right)$. The results of atmospheric $\mathrm{NH}_{3}$ concentrations observed in our study were higher than those observed in some European countries (Flechard et al., 2011). Although the annual $\mathrm{NH}_{3}$ concentration at the sampling site was within the range of regional background $\mathrm{NH}_{3}$ concentration in China (Meng et al., 2010), it exceeded or was very close to the critical level of $3( \pm 1) \mu \mathrm{g} \mathrm{N} / \mathrm{m}^{3}$ that was set for protecting the most fragile regions (Cape et al., 2009). Therefore, the observed atmospheric $\mathrm{NH}_{3}$ concentrations posed a potential environmental threat to the grassland in Inner Mongolia. During the monitoring period, the monthly $\mathrm{NH}_{3}$ concentrations exhibited the highest value in summer and the lowest value in winter. The seasonal variations were caused by season-related human activities and meteorological factors. In summer, high temperature was conducive to enhancing microbial activities and strengthening microbial ammonification. Moreover, high temperature favored ammonia volatilization and also favored $\mathrm{NH}_{3}$ emission from fertilizer application during potato cultivation near the grassland. During the growing season, herdsmen applied $\mathrm{N}$ fertilizer to the grasses to promote the growth of pastures, further elevating the $\mathrm{NH}_{3}$ concentration in summer. In winter, however, the low temperature severely restricted biological activities and the fertilizer application was minimal. Consequently, less ammonia volatilized. High wind speeds in winter also favored the dispersion of pollutants, further lowering the $\mathrm{NH}_{3}$ concentration.

It is commonly accepted that $\mathrm{NO}_{\mathrm{x}}$ is mainly produced in various combustion processes, including those associated with transportation, industry, coal use and power plants (Holland et al., 2005; Paulot et al., 2013). Due to a low level development of industrialization in the sampling site, $\mathrm{NO}_{2}$ concentrations were remarkably lower than those reported in most urban sites in China $(\mathrm{Xu}$ et al., 2016). However, the annual mean $\mathrm{NO}_{2}$ concentration during the monitoring period was more than two times higher than previous value measured by Shen et al. (2009). The recent increase in the numbers of vehicles can partially explain the increased $\mathrm{NO}_{2}$ concentrations. The number of private cars in Inner Mongolia grew from $1.88 \times 10^{6}$ in 2011 to $3.35 \times 10^{6}$ in 2015 
(National Bureau of Statistics of China, 2011-2015). The higher $\mathrm{NO}_{2}$ concentrations were observed in spring and autumn, being inconsistent with typical seasonal variations (Xu et al., 2015). Higher $\mathrm{NO}_{2}$ concentrations in spring might be attributable to coal combustion for domestic heating. $\mathrm{HNO}_{3}$ exhibited high concentrations in autumn and low concentrations in summer, being consistent with the seasonal variations of $\mathrm{NO}_{2}$.

The annual mean $\mathrm{pNH}_{4}{ }^{+}$concentration measured in the present study was much lower than many other observations in China (Xu et al., 2015) and in west Europe (Holland et al., 2005), but it was comparable to that measured at rural sites in USA (Li et al., 2016) and was higher than that reported in UK (Marner and Harrison, 2004). The concentration of $\mathrm{pNH}_{4}{ }^{+}$in summer was higher than those measured in spring, autumn or winter. The high $\mathrm{NH}_{3}$ concentration and high relative humidity in summer were likely important causes of this phenomenon. High concentration of $\mathrm{NH}_{3}$ and high relative humidity both favored the transition from gaseous $\mathrm{NH}_{3}$ to particulate $\mathrm{NH}_{4}{ }^{+}$, although increased temperatures did not favor particulate ammonium nitrate formation. Because of the low $\mathrm{HNO}_{3}$ concentrations, the $\mathrm{pNO}_{3}{ }^{-}$concentrations were lower than most results measured in China (Pan et al., 2012; $\mathrm{Xu}$ et al., 2015). The seasonal pattern of $\mathrm{pNO}_{3}{ }^{-}$ concentrations was the same as that of $\mathrm{pNH}_{4}{ }^{+}$concentrations with the higher values in summer and lower values in other seasons.

$\mathrm{N}$ in precipitation mainly derived from water-soluble atmospheric $\mathrm{Nr}$ components. These pollutants were scavenged from the air by rainfall or snowfall. The annual concentrations of $\mathrm{NH}_{4}{ }^{+}-\mathrm{N}$ and $\mathrm{NO}_{3}{ }^{-}-\mathrm{N}$ in wet/bulk deposition in the sampling site were also lower than those reported in many previous studies conducted in urban and rural sites in China (Pan et al., 2012; Huang et al., 2013), but they were higher than those observed in a semi-arid region in Urumqi (Li et al., 2012). In our study, the highest monthly average concentrations of $\mathrm{NH}_{4}{ }^{+}-\mathrm{N}$ and $\mathrm{NO}_{3}{ }^{-} \mathrm{N}$ occurred in summer and the lowest in winter, showing a significant negative correlation between $\mathrm{N}$ concentration and precipitation. This pattern suggests a dilution effect of precipitation on $\mathrm{N}$ concentrations (Jia and Chen, 2010; Kuang et al., 2016). Compared with previously published data (Xu et al., 2015), annual concentration of $\mathrm{NH}_{4}{ }^{+}-\mathrm{N}$ in precipitation increased by $19 \%$ while annual concentration of $\mathrm{NO}_{3}^{-}-\mathrm{N}$ reduced by $6 \%$ in grassland of Duolun County.

\subsection{Seasonal variations of wet/bulk and dry $\mathrm{N}$ deposition}

A different seasonal pattern of $\mathrm{N}$ deposition was observed at the sampling site (Fig. 4). The highest deposition fluxes of $\mathrm{Nr}$ components occurred in summer and the lowest values always appeared in winter with an exception of $\mathrm{HNO}_{3}$ that had the highest deposition flux in autumn. In summer, $\mathrm{NH}_{3}$ deposition fluxes were markedly higher than those in spring, autumn and winter, accounting for $57 \%$ of the annual $\mathrm{NH}_{3}$ deposition flux. This is consistent with the seasonal variation of $\mathrm{NH}_{3}$ concentration. Deposition fluxes of $\mathrm{NO}_{2}$ and $\mathrm{pNH}_{4}{ }^{+}$in summer dominated the annual deposition. Deposition of $\mathrm{pNH}_{4}{ }^{+}$in spring, autumn and winter contributed equally to the annual deposition, and the seasonal variations of $\mathrm{pNO}_{3}{ }^{-}$deposition were similar to those of $\mathrm{pNH}_{4}{ }^{+}$ deposition. Compared with other $\mathrm{Nr}$ components, the flux of $\mathrm{HNO}_{3}$ dry deposition showed different seasonal variations with the highest value in autumn, contributing $56 \%$ of estimated annual $\mathrm{HNO}_{3}$ deposition. This pattern can be partially explained by the higher concentrations and higher deposition velocities of $\mathrm{HNO}_{3}$ in autumn. Due to different emission sources and different meteorological conditions, the percentage contribution of individual $\mathrm{Nr}$ component to the total dry $\mathrm{N}$ deposition varied with geographical locations. In the current study, $\mathrm{NH}_{3}$ contributed the most to the total dry $\mathrm{N}$ deposition (51\%). This value was significantly higher than the contributions of $\mathrm{NO}_{2}(18 \%), \mathrm{HNO}_{3}(10 \%), \mathrm{pNH}_{4}{ }^{+}(15 \%)$, and $\mathrm{pNO}_{3}^{-}(6 \%)$ to the total dry $\mathrm{N}$ deposition. The gaseous $\mathrm{Nr}$ components accounted for $79 \%$ of the total dry $\mathrm{N}$ deposition in our study, being highly consistent with the finding in North China Plain (Xu et al., 2016).

Similar to dry $\mathrm{N}$ deposition, wet/bulk deposition fluxes of $\mathrm{NH}_{4}{ }^{+}-\mathrm{N}$ and $\mathrm{NO}_{3}{ }^{-} \mathrm{N}$ and total $\mathrm{N}$ deposition were higher in summer than in other seasons, being in a good agreement with the seasonal distributions of precipitation at the sampling site. In summer, precipitation accounted for $62 \%$ of the annual total, while in winter, precipitation was relatively small. Positive relationships between precipitation amounts and wet $\mathrm{N}$ deposition fluxes have been reported in many previous 
observations (e.g., Pan et al., 2012; Huang et al., 2013). Deposition fluxes of $\mathrm{NH}_{4}{ }^{+}-\mathrm{N}$ and $\mathrm{NO}_{3}{ }^{-} \mathrm{N}$ in summer (average values of 2.64 and $1.41 \mathrm{~kg} \mathrm{~N} /\left(\mathrm{hm}^{2} \cdot \mathrm{a}\right)$, respectively) contributed $49 \%$ and $44 \%$ to the annual wet/bulk deposition, respectively. Both higher precipitation amounts and high atmospheric concentrations of $\mathrm{Nr}$ components contributed to the high $\mathrm{N}$ deposition fluxes in summer. The deposition flux of $\mathrm{NH}_{4}{ }^{+}-\mathrm{N}$ was 1.87 times that of $\mathrm{NO}_{3}{ }^{-}-\mathrm{N}$ in summer, 1.85 times in spring, 1.07 times in autumn and 1.07 times in winter. The ratio of $\mathrm{NH}_{4}{ }^{+}-\mathrm{N}$ concentration to $\mathrm{NO}_{3}{ }^{-} \mathrm{N}$ concentration is widely perceived as an indicator of the sources of atmospheric $\mathrm{Nr}$ components (Huang et al., 2013). Specifically, when the ratio is larger than 1, it is commonly accepted that $\mathrm{Nr}$ mainly originated from agricultural activities; whereas it is commonly accepted that $\mathrm{Nr}$ mainly originated from industrial activities when the ratio is lower than 1 (Xu et al., 2015). In this study, the ratios of $\mathrm{NH}_{4}{ }^{+}-\mathrm{N}$ concentration to $\mathrm{NO}_{3}{ }^{-}-\mathrm{N}$ concentration in summer and spring indicated that $\mathrm{N}$ in wet/bulk deposition mainly originated from agricultural activities. In autumn and winter, the contributions of agricultural and industrial activities to wet/bulk $\mathrm{N}$ deposition were equal.

\subsection{Comparison of oxidized and reduced $\mathrm{N}$ in dry and wet/bulk deposition}

During the monitoring period, the annual mean fluxes of oxidized (e.g., $\mathrm{HNO}_{3}$ and $\mathrm{pNO}_{3}{ }^{-}$) and reduced (e.g., $\mathrm{NH}_{3}$ and $\mathrm{pNH}_{4}{ }^{+}$) dry $\mathrm{N}$ deposition were 2.12 and $4.09 \mathrm{~kg} \mathrm{~N} /\left(\mathrm{hm}^{2}\right.$.a), respectively. Dry $\mathrm{N}$ deposition estimated in the current study was obviously lower than those observed in northern China (Shen et al., 2009; Pan et al., 2012; Luo et al., 2013) but higher than those monitored at rural sites in Canada (Zhang et al., 2009). The reduced $\mathrm{N}$ accounted for $66 \%$ of dry $\mathrm{N}$ deposition, being consistent with previous studies conducted in China (Xu et al., 2015). $\mathrm{NH}_{3}$ deposition accounted for $78 \%$ of dry reduced $\mathrm{N}$ deposition. It's universally acknowledged that the major sources of atmospheric $\mathrm{NH}_{3}$ are livestock wastes and agricultural $\mathrm{N}$ fertilizers (Duan et al., 2016). According to Kuang et al. (2016), the amounts of $\mathrm{NH}_{3}$ emitted from chemical fertilizer use and animal husbandry in China increased from 4.9 Tg N in 1980 to $8.0 \mathrm{Tg} \mathrm{N}$ in 2012. The amount of agricultural fertilizer application increased by 13\% from 2011 to 2015 in Inner Mongolia (National Bureau of Statistics of China, 2011-2015). $\mathrm{NO}_{2}$ was the largest contributor to oxidized $\mathrm{N}$ in dry deposition, followed by $\mathrm{HNO}_{3}$ and $\mathrm{pNO}_{3}{ }^{-}$. The mean deposition fluxes of $\mathrm{NO}_{2}, \mathrm{HNO}_{3}$ and $\mathrm{pNO}_{3}{ }^{-}$were $1.13,0.63$ and $0.36 \mathrm{~kg} \mathrm{~N} /\left(\mathrm{hm}^{2} \cdot \mathrm{a}\right)$, respectively, corresponding to $53 \%, 30 \%$ and $17 \%$ of oxidized $\mathrm{N}$ in dry deposition. $\mathrm{NH}_{3}$ and $\mathrm{NO}_{2}$ were the two major contributors of dry $\mathrm{N}$ deposition at the sampling site, together contributing to $69 \%$ of dry $\mathrm{N}$ deposition. $\mathrm{NO}_{2}$ is a precursor to $\mathrm{HNO}_{3}$. $\mathrm{NH}_{3}$ can react with acid gases such as $\mathrm{H}_{2} \mathrm{SO}_{4}$ and $\mathrm{HNO}_{3}$ in the air, promoting the formation of $\mathrm{PM}_{2.5}$. $\mathrm{PM}_{2.5}$ reduces atmospheric visibility and long-term exposure to elevated $\mathrm{PM}_{2.5}$ concentrations can result in respiratory and cardiovascular diseases (Zheng et al., 2015). Due to strict standards of implementation and technical improvements to limit atmospheric pollution, $\mathrm{NO}_{\mathrm{x}}$ emissions almost dropped by $41 \%$ from 1990 to 2010 in USA (Li et al., 2016). Butler et al. (2005) quantified the effect of reduced emission of $\mathrm{NO}_{\mathrm{x}}$ on $\mathrm{N}$ deposition and the results showed that when $\mathrm{NO}_{x}$ emissions were reduced by $50 \%$, the total $\mathrm{NO}_{3}{ }^{-}$deposition would be decreased by $37 \%$ and the total $\mathrm{N}$ deposition would be dropped by $25 \%$. This work well manifested the importance of controlling $\mathrm{NO}_{\mathrm{x}}$ emissions, especially in regions upwind of sensitive ecosystems. China also has made efforts to control $\mathrm{NO}_{\mathrm{x}}$ emissions. For example, in the $12^{\text {th }}$ Five-Year-Plan (2011-2015), $\mathrm{NO}_{\mathrm{x}}$ emission was proposed to reduce by $10 \%$. And, in late 2012, a stricter $\mathrm{NO}_{\mathrm{x}}$ emission standard was released by Ministry of Environmental Protection of the People's Republic of China (http://www.zhb.gov.cn/). However, we still have a long way to go to controlling $\mathrm{N}$ deposition.

Deposition fluxes of $\mathrm{NH}_{4}{ }^{+}-\mathrm{N}$ and $\mathrm{NO}_{3}{ }^{-}-\mathrm{N}$ in precipitation at the sampling site were lower than those in regions with serious $\mathrm{N}$ pollution in northern China (Pan et al., 2012). However, compared with the values estimated in Europe, the wet/bulk deposition fluxes in the current study were higher (Cape et al., 2012). Wet/bulk N deposition fluxes in the current study were also higher than those in Urumqi of Xinjiang (Li et al., 2012). Zhu et al. (2015) found that wet $\mathrm{N}$ deposition, precipitation, $\mathrm{N}$ fertilizer application, and energy consumption were closely related and, therefore, wet $\mathrm{N}$ deposition could be reduced to acceptable levels by cutting down energy consumption and 
also by lessening $\mathrm{N}$ fertilizer application. Reduced $\mathrm{N}$ dominated wet/bulk deposition with a contribution of $63 \%$, being similar to the results reported in USA (Li et al., 2016). Li et al. (2016) pointed out that wet $\mathrm{N}$ deposition in USA changed in recent decades from being nitrate-dominated to ammonium-dominated and that the changes were due to decreases in nitrate wet deposition fluxes in most regions (consistent with $\mathrm{NO}_{\mathrm{x}}$ emission reductions) and increases in ammonium wet deposition. In China, the reduced $\mathrm{N}$ also dominates the total $\mathrm{N}$ deposition, but the percentage of oxidized $\mathrm{N}$ in total deposition is increasing rapidly (Liu et al., 2016), demonstrating the importance of implementing continuous $\mathrm{NO}_{\mathrm{x}}$ emission control measures.

Total inorganic $\mathrm{N}$ deposition (dry and wet/bulk) was $14.7 \mathrm{~kg} \mathrm{~N} /\left(\mathrm{hm}^{2} \cdot \mathrm{a}\right)$ in the present study, being close to the upper limit of the $\mathrm{N}$ critical load $\left(10-15 \mathrm{~kg} \mathrm{~N} /\left(\mathrm{hm}^{2} \cdot \mathrm{a}\right)\right.$ ) (Bobbink et al., 2010). In this study, about $58 \%$ of the total $\mathrm{N}$ deposition was from wet/bulk deposition and $42 \%$ from dry deposition. The annual mean $\mathrm{N}$ deposition measured from this study was slightly higher than that estimated at Ireland grasslands (Henry and Aherne, 2014), but was lower than the values in most studies carried out in different sites in China (Pan et al., 2012; Xu et al., 2015). The fractional contribution of dry $\mathrm{N}$ deposition in the current study (42\%) was lower than those in most studies in China (Pan et al., 2012; Wang et al., 2013; Xu et al., 2015; Kuang et al., 2016).

Reduced $\mathrm{N}$ constituted $64 \%$ of the total $\mathrm{N}$ deposition in the current study, 1.5 times higher than the contribution from oxidized $\mathrm{N}$. Experimental studies have shown that reduced $\mathrm{N}$ is more effective than oxidized $\mathrm{N}$ in driving the decline of biodiversity in acidic and mesotrophic grasslands (Stevens et al., 2011). The currently recognized $\mathrm{N}$ saturation critical load in terrestrial ecosystems is $10-15 \mathrm{~kg} \mathrm{~N} /\left(\mathrm{hm}^{2} \cdot a\right)$, a value derived from field experiments (Bai et al., 2010). Total $\mathrm{N}$ deposition obtained from the current study exceeded the lowest critical load value and may potentially pose threats to ecosystems. Field $\mathrm{N}$ addition experiments conducted on temperate grassland in Inner Mongolia indicated that increased $\mathrm{N}$ deposition led to a decrease of plant species richness (Zeng et al., 2016) and an alteration of species composition of plant communities (Duprè et al., 2010), posing a threat to ecosystem stability. In addition, when $\mathrm{N}$ deposition increases, a sizable species richness loss is expected in regions with low $\mathrm{N}$ deposition (Stevens et al., 2011).

\section{Conclusions}

Average $\mathrm{N}$ deposition from atmosphere and precipitation was estimated to be $14.7 \mathrm{~kg} \mathrm{~N} /\left(\mathrm{hm}^{2} \cdot \mathrm{a}\right)$ during the period from 2013 to 2015 in a semi-arid grassland in Duolun County of Inner Mongolia, being close to the upper limit of the $\mathrm{N}$ critical load $\left(10-15 \mathrm{~kg} \mathrm{~N} /\left(\mathrm{hm}^{2} \cdot \mathrm{a}\right)\right)$ in most grassland ecosystems. Specifically, $58 \%$ of total $\mathrm{N}$ deposition came from wet/bulk deposition and $42 \%$ from dry deposition. Gaseous $\mathrm{N}$ deposition pathways dominated dry deposition with a contribution of $79 \%$. Among gaseous $\mathrm{Nr}$ components, $\mathrm{NH}_{3}$ and $\mathrm{NO}_{2}$ were the most important parts, accounting for $69 \%$ of dry deposition. Affected by emission sources and meteorological conditions, dry depositions of most $\mathrm{Nr}$ components (with an exception of $\mathrm{HNO}_{3}$ ) exhibited relatively similar seasonal patterns: the highest deposition flux occurred in summer and the lowest in winter. The highest concentrations of $\mathrm{NH}_{4}{ }^{+}-\mathrm{N}$ and $\mathrm{NO}_{3}{ }^{-}-\mathrm{N}$ in precipitation were observed in summer. In addition, a widely-reported negative correlation between inorganic $\mathrm{N}$ concentrations and precipitation amounts was also observed in the present study. Since N deposition fluxes in summer contributed the most to the annual $\mathrm{N}$ deposition value and high fluxes were partially attributable to agricultural and industrial activities, attentions should be paid to restraining the agricultural and industrial activities in summer in order to reduce $\mathrm{N}$ deposition.

Our work provides useful information on the background $\mathrm{N}$ deposition flux of Inner Mongolia Grassland and the results can serve as a reference when conducting manipulative field experiments in this semi-arid region. Although total $\mathrm{N}$ deposition measured from our study indicated that Duolun County was not as heavily polluted as many other developed regions in China, it is worth noting that the observed $\mathrm{N}$ deposition exceeded the lowest established critical value and could pose threats to grassland ecosystems. 


\section{Acknowledgements}

This work was financially supported by the National Key R\&D Program of China (2017YFC0210101, 2014CB954202) and the National Natural Science Foundation of China (41425007).

\section{References}

Bai Y F, Wu J G, Clark C M, et al. 2010. Tradeoffs and thresholds in the effects of nitrogen addition on biodiversity and ecosystem functioning: Evidence from Inner Mongolia Grasslands. Global Change Biology, 16(1): 358-372.

Bobbink R, Hicks K, Galloway J, et al. 2010. Global assessment of nitrogen deposition effects on terrestrial plant diversity: A synthesis. Ecological Applications, 20(1): 30-59.

Butler T J, Likens G E, Vermeylen F M, et al. 2005. The impact of changing nitrogen oxide emissions on wet and dry nitrogen deposition in the northeastern USA. Atmospheric Environment, 39(27): 4851-4862.

Cape J N, van der Eerden L J, Sheppard L J, et al. 2009. Evidence for changing the critical level for ammonia. Environmental Pollution, 157(3): 1033-1037.

Cape J N, Tang Y S, González-Beníez J M, et al. 2012. Organic nitrogen in precipitation across Europe. Biogeosciences, 9(11): 4401-4409.

Ceulemans T, Hulsmans E, Berwaers S, et al. 2017. The role of above-ground competition and nitrogen vs. phosphorus enrichment in seedling survival of common European plant species of semi-natural grasslands. PLoS ONE, 12(3): e0174380. https://doi.org/10.1371/journal.pone.0174380.

Dai E F, Huang Y, Wu Z, et al. 2016. Analysis of spatio-temporal features of a carbon source/sink and its relationship to climatic factors in the Inner Mongolia grassland ecosystem. Journal of Geographical Sciences, 26(3): 297-312.

Duan L, Yu Q, Zhang Q, et al. 2016. Acid deposition in Asia: Emissions, deposition, and ecosystem effects. Atmospheric Environment, 146: 55-69.

Duprè C, Stevens C J, Ranke T, et al. 2010. Changes in species richness and composition in European acidic grasslands over the past 70 years: The contribution of cumulative atmospheric nitrogen deposition. Global Change Biology, 16(1): 344-357.

Flechard C R, Nemitz E, Smith R I, et al. 2011. Dry deposition of reactive nitrogen to European ecosystems: A comparison of inferential models across the NitroEurope network. Atmospheric Chemistry and Physics, 11(6): 2703-2728.

Fowler D, Coyle M, Skiba U, et al. 2013. The global nitrogen cycle in the twenty-first century. Philosophical Transactions of the Royal Society B: Biological Sciences, 368(1621): 20130164.

Galloway J N, Dentener F J, Capone D G, et al. 2004. Nitrogen cycles: Past, present, and future. Biogeochemistry, 70(2): $153-226$.

Gruber N, Galloway J N. 2008. An Earth-system perspective of the global nitrogen cycle. Nature, 451(7176): $293-296$.

He K J, Qi Y, Huang Y M, et al. 2016. Response of aboveground biomass and diversity to nitrogen addition-a five-year experiment in semi-arid grassland of Inner Mongolia, China. Scientific Reports, 6: 31919.

Henry J, Aherne J L. 2014. Nitrogen deposition and exceedance of critical loads for nutrient nitrogen in Irish grasslands. Science of the Total Environment, 470-471: 216-223.

Holland E A, Braswell B H, Sulzman J, et al. 2005. Nitrogen deposition onto the United States and western Europe: Synthesis of observations and models. Ecological Applications, 15(1): 38-57.

Huang Y L, Lu X X, Chen K. 2013. Wet atmospheric deposition of nitrogen: 20 years measurement in Shenzhen City, China. Environmental Monitoring and Assessment, 185(1): 113-122.

National Bureau of Statistics of China. 2011-2015. Inner Mongolia Statistics Yearbook. http://www.stats.gov.cn. (in Chinese)

Jia G D, Chen F J. 2010. Monthly variations in nitrogen isotopes of ammonium and nitrate in wet deposition at Guangzhou, south China. Atmospheric Environment, 44(19): 2309-2315.

Jia Y L, Yu G R, Gao Y N, et al. 2016. Global inorganic nitrogen dry deposition inferred from ground- and space-based measurements. Scientific Reports, 6: 19810.

Kuang F H, Liu X J, Zhu B, et al. 2016. Wet and dry nitrogen deposition in the central Sichuan Basin of China. Atmospheric Environment, 143: 39-50.

Li K H, Zhang W, Shen J L, et al. 2012. Dry and wet deposition of inorganic nitrogen at urban and rural sites in a semi-arid environment. In: 2012 International Conference on Biomedical Engineering and Biotechnology. Macau, Macao, China: 
IEEE, 1367-1370.

Li K H, Liu X J, Song L, et al. 2015. Response of alpine grassland to elevated nitrogen deposition and water supply in China. Oecologia, 177(1): 65-72

Li Y, Schichte B A, Walker J T, et al. 2016. Increasing importance of deposition of reduced nitrogen in the United States. Proceedings of the National Academy of Scicences of the United States of America, 113(21): 5874-5879.

Liu J Y, Zhang Y, Liu X J, et al. 2016. Concentrations and isotopic characteristics of atmospheric reactive nitrogen around typical sources in Beijing, China. Journal of Arid Land, 8(6): 910-920.

Liu X J, Duan L, Mo J M, et al. 2011. Nitrogen deposition and its ecological impact in China: An overview. Environmental Pollution, 159(10): 2251-2264.

Liu X J, Zhang Y, Han W X, et al. 2013. Enhanced nitrogen deposition over China. Nature, 494(7438): 459-462.

Liu X J, Xu W, Du E Z, et al. 2016. Reduced nitrogen dominated nitrogen deposition in the United States, but its contribution to nitrogen deposition in China decreased. Proceedings of the National Academy of Scicences of the United States of America, 113(26): E3590-E3591.

Luo X S, Liu P, Tang A H, et al. 2013. An evaluation of atmospheric $\mathrm{N}_{\mathrm{r}}$ pollution and deposition in North China after the Beijing Olympics. Atmospheric Environment, 74: 209-216.

Marner B B, Harrison R M. 2004. A spatially refined monitoring based study of atmospheric nitrogen deposition. Atmospheric Environment, 38(30): 5045-5056.

Meng Z Y, Xu X B, Wang T, et al. 2010. Ambient sulfur dioxide, nitrogen dioxide, and ammonia at ten background and rural sites in China during 2007-2008. Atmospheric Environment, 44(21-22): 2625-2631.

Ni J. 2004. Estimating net primary productivity of grasslands from field biomass measurements in temperate northern China. Plant Ecology, 174(2): 217-234.

Nogueira C, Bugalho M N, Pereira J S, et al. 2017. Extended autumn drought, but not nitrogen deposition, affects the diversity and productivity of a Mediterranean grassland. Environmental and Experimental Botany, 138: 99-108.

Ochoa-Hueso R, Allen E B, Branquinho C, et al. 2011. Nitrogen deposition effects on Mediterranean-type ecosystems: An ecological assessment. Environmental Pollution, 159(10): 2265-2279.

Pan Y P, Wang Y S, Tang G Q, et al. 2012. Wet and dry deposition of atmospheric nitrogen at ten sites in Northern China. Atmospheric Chemistry and Physics, 12(14): 6515-6535.

Pan Y P, Tian S L, Liu D W, et al. 2016a. Fossil fuel combustion-related emissions dominate atmospheric ammonia sources during severe haze episodes: Evidence from ${ }^{15} \mathrm{~N}$-stable isotope in size-resolved aerosol ammonium. Environmental Science \& Technology, 50(15): 8049-8056.

Pan Y P, Wang Y S, Zhang J K, et al. 2016b. Redefining the importance of nitrate during haze pollution to help optimize an emission control strategy. Atmospheric Environment, 141: 197-202.

Paulot F, Jacob D J, Henze D K. 2013. Sources and processes contributing to nitrogen deposition: An adjoint model analysis applied to biodiversity hotspots worldwide. Environmental Science \& Technology, 47(7): 3226-3233.

Shen J L, Tang A H, Liu X J, et al. 2009. High concentrations and dry deposition of reactive nitrogen species at two sites in the North China Plain. Environmental Pollution, 157(11): 3106-3113.

Song L, Bao X M, Liu X J, et al. 2012. Impact of nitrogen addition on plant community in a semi-arid temperate steppe in China. Journal of Arid Land, 4(1): 3-10.

Stevens C J, Manning P, van den Berg L J L, et al. 2011. Ecosystem responses to reduced and oxidised nitrogen inputs in European terrestrial habitats. Environmental Pollution, 159(3): 665-676.

Tang Z S, Deng L, An H, et al. 2017. The effect of nitrogen addition on community structure and productivity in grasslands: A meta-analysis. Ecological Engineering, 99: 31-38.

Vet R, Artz R S, Carou S, et al. 2014. A global assessment of precipitation chemistry and deposition of sulfur, nitrogen, sea salt, base cations, organic acids, acidity and pH, and phosphorus. Atmospheric Environment, 93: 3-100.

Wang R Z, Dungait J A J, Buss H L, et al. 2017. Base cations and micronutrients in soil aggregates as affected by enhanced nitrogen and water inputs in a semi-arid steppe grassland. Science of the Total Environment, 575: 564-572.

Wang X M, Wu Z Y, Shao M, et al. 2013. Atmospheric nitrogen deposition to forest and estuary environments in the Pearl River Delta region, southern China. Tellus B: Chemical and Physical Meteorology, 65(1): 20480.

Wedin D A, Tilman D. 1996. Influence of nitrogen loading and species composition on the carbon balance of grasslands. 
Science, 274(5293): 1720-1723.

Xu W, Luo X S, Pan Y P, et al. 2015. Quantifying atmospheric nitrogen deposition through a nationwide monitoring network across China. Atmospheric Chemistry and Physics, 15(21): 12345-12360.

$\mathrm{Xu} \mathrm{W,} \mathrm{Wu} \mathrm{Q} \mathrm{H,} \mathrm{Liu} \mathrm{X} \mathrm{J,} \mathrm{et} \mathrm{al.} \mathrm{2016.} \mathrm{Characteristics} \mathrm{of} \mathrm{ammonia,} \mathrm{acid} \mathrm{gases,} \mathrm{and} \mathrm{PM}_{2.5}$ for three typical land-use types in the North China Plain. Environmental Science and Pollution Research, 23(2): 1158-1172.

Yang R, Hayashi K, Zhu B, et al. 2010. Atmospheric $\mathrm{NH}_{3}$ and $\mathrm{NO}_{2}$ concentration and nitrogen deposition in an agricultural catchment of Eastern China. Science of the Total Environment, 408(20): 4624-4632.

Zeng J, Liu X J, Song L, et al. 2016. Nitrogen fertilization directly affects soil bacterial diversity and indirectly affects bacterial community composition. Soil Biology and Biochemistry, 92: 41-49.

Zhang L M, Vet R, O’Brien J M, et al. 2009. Dry deposition of individual nitrogen species at eight Canadian rural sites. Journal of Geophysical Research, 114(D2): D02301.

Zhang M, Jacob D J, Knipping E M, et al. 2012. Nitrogen deposition to the United States: Distribution, sources, and processes. Atmospheric Chemistry and Physics, 12(10): 4539-4554.

Zhao Y H, Zhang L, Chen Y F, et al. 2017. Atmospheric nitrogen deposition to China: A model analysis on nitrogen budget and critical load exceedance. Atmospheric Environment, 153: 32-40.

Zheng G J, Duan F K, Su H, et al. 2015. Exploring the severe winter haze in Beijing: The impact of synoptic weather, regional transport and heterogeneous reactions. Atmospheric Chemistry and Physics, 15(6): 2969-2983.

Zhu J X, He N P, Wang Q F, et al. 2015. The composition, spatial patterns, and influencing factors of atmospheric wet nitrogen deposition in Chinese terrestrial ecosystems. Science of the Total Environment, 511: 777-785. 